American Journal of Economics and Business Administration 2 (3): 253-265, 2010

ISSN 1945-5488

(C) 2010 Science Publications

\title{
Cross European Financial Networks Related to Turkish Immigrants and their Businesses: The Case of Turkish-Owned Commercial Bank Under Dutch Legislation
}

\author{
Shahamak Rezaei \\ Department of Society and Globalization, Roskilde University, Denmark
}

\begin{abstract}
Problem statement: Understanding the character and strategies of ethnic economy and ethnic enclave economy this study concluded, that it is necessary to look beyond and within the demarcation of national background and even ethnic boundaries in a broader sense according to which these phenomena mistakenly had been attempted to be explained. The engine of ethnic enclave economy cannot be upheld without a core, entrance into which requires both more than common national and ethnic background. The challenge for this economy is how to dissolve from strong ties to more loose organization based on rationally structured mode of organization. However, the case presented here DHB Bank (Nederland) N.V. illustrates a successful international financial provider in the globalization era with specialization in financial trade with a limited group of co-ethnic agents who stick together in order to remain in control of this world-wide multi billion financial service provided by the bank. DHB Bank (Nederland) N.V was established in Rotterdam in 1992 as a Turkish-owned commercial bank under Dutch law. Conclusion/Recommendations: Trade finance, particularly for Turkish corporations and their Western European business partners, was a major focus of our business from the start. However, began the bank quickly to expand the consumer banking services offered and opened the first, centrally located branch offices in Amsterdam, Rotterdam and The Hague in 1995. In 1997, the bank began establishing an international presence by expanding into Germany: where now having a network of offices in Düsseldorf, Hamburg, Stuttgart, Berlin and Munich. DHB Bank (Nederland) N.V. entered the Belgian market in 1999 and currently has branches in Brussels and Antwerp. Today (2010), the bank provides a full range of both trade finance and consumer banking services and products in all these cities, including internet banking, which was launched in 2001. All branch offices work closely and directly with the corporate liaison office in Istanbul, Turkey.
\end{abstract}

Key words: Globalization, bounded ethnic solidarity, ethnic entrepreneurship, ethnic enclave economy, ethnic business break-out, weak ties and strong ties

\section{INTRODUCTION}

Demir-Halk Bank (DHB Bank) is a relatively young bank. It was established in 1992 as a joint venture of two Turkish Banks, Demirbank T.A.S and Halkbank. Demirbank T.A.S. of Istanbul is a privately owned bank whose shares are traded on the Istanbul, Frankfurt and Munich stock exchanges. Türkiye Halk Bankasi of Ankara (hereafter referred to as Halkbank) is the second-largest state-owned bank in Turkey in terms of asset size. Both banks were looking to expand their business into Western Europe and opted for an independent subsidiary headquartered in the Netherlands rather than a simple expansion of their branch network. Demirbank and the financial holding company to which it belongs, Cingilli Holding, the major shareholder of Demir-Halk Bank (the Netherlands) N.V. During 1999 and 2002, the bank's shareholder structure was changed. After the transfer of the shares in 1999, previously held by Cingilli Holding to Demirbank T.A.S., the latter now controls $70 \%$ of capital, while the remaining $30 \%$ is held by TUrkiye Halk Bankasi A.S. From the outset, trade finance has been a major business focus for DHB Bank. This made it appear logical to locate at one of the major crossroads of trade in Western Europe, the Dutch city of Rotterdam. Accordingly, DHB Bank registered as a Dutch bank under Dutch legislation. The specialty of DHB Bank is the provision of trade finance services for Turkish corporations and small businesses and their Western European business partners. Since Turkey is the most important market for DHB Bank, the Istanbul representative office liaises between DHB Bank and Turkey.

Soon after its establishment, DHB Bank began to expand the retail services it provided, mainly to Turkish Diaspora in the Netherlands and branches were established in central locations in Amsterdam, 
Rotterdam, The Hague and Utrecht. In 1997, DHB Bank took its first step towards building an international presence in the European market and established the Dusseldorf branch which provides the full range of DHB's services in both trade finance and retail banking (DHB Bank N.V., 1997). This development has continued in a way that today the activities of DHB Bank can be found in several German cities as well as Belgium and there are also plans for establishing activities in a number of European cities as well as the United Kingdom. Thus, DHB Bank is now a Turkish owned bank, registered in the Netherlands and operating across northern Europe.

Since its modest beginnings 18 years ago (in 1992), Demir-Halk Bank has come a long way. The bank had in 1999 a paid-up capital of NLG 100 million, with a balance sheet of more than NLG one billion. In step with the continuous expansion in DHB Bank's business volume, staff numbers have also grown. This trend has been continuing also during the current financial crisis and the number of employees as well as number of branches in 2008 has been the largest ever. The dominant organizational characteristic is the strong dominance of co ethnic employees and clientele of Turkish descent. Although the bank's policy and services have not been developed with the ethnic community in mind, in practice the operation of the bank is quite mono-ethnic when it comes to client type and employees. Approximately $96 \%$ of employees and most of its clients are of Turkish descent.

Theoretical perspectives: The dynamics of migration, immigrant business formation and financial networking.

A significant number of labor migrants residing in northern European countries has, over the years, returned their savings as remittances to their country of origin either as a supplementary source of income to family and relatives or to start new businesses in their country of origin while, on the other hand, some other migrants are trying to raise loan capital to start new businesses in their country of residence. To be able to conduct these kinds of financial transactions a system of financial institutions is needed. Bager (1998) presents three different forms of organizing of financial institutions which are used by migrants: (1) Informal person-to-person financing; (2) Semi-formal institutions of financing such as exchange bureaus, private lenders and rotating credit associations; (3) Formal financial institutions such as banks. While the two first stated forms are mainly based on mutual trust and are most common within families and friends the latter form is more general and adoptable based on creditworthiness. It is here that the existence of financial institutions such as DHB Bank can be significant. The question is whether "creditworthiness" is "ethnic-sensitive" or "ethnic blind"?

The study of DHB bank may add to theoretical debates in at least three fields: Forms of globalization; concept of ethnic business and bounded solidarity and the shaping of business relations.

The immigrant business phenomenon, which is often labeled "ethnic business", has been studied intensively within the field of economic sociology, particularly in the USA (Granovetter and Swedberg, 1991; Waldinger et al., 1990; Yeung and Olds, 1999) but one also finds numerous studies which focus on the business and organizational side (Aldrich and Zimmer, 1987; Aldrich et al., 1989; Light, 1972; Light and Rosenstein, 1995; Weber, 1968; Yinger, 1985). Moreover, the field clearly benefits from general economic and organizational theory on entrepreneurship, small-firm networks and institutional mechanisms in organizational life (Dimaggio and Powell, 1991; Perrow, 1993).

Traditionally, ethnic businesses starts as small family units, but over the years it is normal, that some spin-off of larger immigrant controlled companies. In some cases, however, particularly in East Asia, immigrant businesses also encompass numerous large firms which may even dominate economic sectors or entire national economies (cf. Redding's study of Chinese businesses in East Asian countries (1990)). And increasingly, the traditional ill-educated and poor type of immigrant, is being substituted by the well-educated and wealthy immigrant, particularly in countries like Canada, the USA and Australia which are open to this type of immigration. This modern type of migration and immigrant business is more international in its orientation than the traditional type and often such immigrants operate businesses in more than one country (Chan, 1992; Li, 1993; Ong et al., 1994; Yeung and Olds, 1999). These studies in various parts of the world suggest that both the old type of loose coupling of immigrant businesses across borders, as well as the modern and more systemic type of international integration of immigrant businesses, may be of relevance to our understanding of how immigrant businesses in one country are linked to similar business communities in neighboring countries as well as to immigrants' countries of origin.

Internationalization processes are usually understood as large firm driven, with large firms becoming international or global more quickly and more extensively than SMEs and with SMEs often being understood only as sub-suppliers to the large, international units and hence as reactive rather than proactive. 
Although this conceptualization seems to capture the main current in the internationalization process, there are strong indications of a serious large-firm bias in this standard conceptualization. Small firms may group together horizontally in national or international networks to gain international competitive strength and a more proactive role in the restructuring process; or SMEs may be born international rather than sticking to the standard model of local/national growth preceding internationalization; or SMEs may be embedded in international social networks which link together even tiny business units at the international scene and sometimes result in surprising semi standardization of certain types of businesses across borders. A substantial proportion of international business is still conducted by family firms organized along kinship lines (Iyer and Sharipo, 1999) and through trading diasporas. Trading diasporas share several features, such as strong ethnic identity and mutual dependence, informal networks based on mutual trust and family reputation and a belief in the utility of knowledge from all possible sources (Kotkin, 1994). The formation of international business centers through trading diasporas around the world, such as Roterdam, London, New York, Hong Kong, Dubai and Hamburg has created supra-national suppliers of goods and services which through formal and informal business networks function as commercial and financial connection points between immigrant business communities and immigrants' countries of origin. The formation of immigrant business networks across countries can be understood as a "bottom-up" globalization process, which complements the standard large firm/top-down one.

A second theoretical prospective of relevance to this study concerns the concept of ethnicity. Broadly stated, ethnic groups are those groups that "entertain a subjective belief in their common descent because of similarities of physical type or of customs or both, or because of memories of colonization and migration" (Weber, 1968). In principle, everyone is ethnic. Geertz (1963) suggests a more stringent definition of ethnic groups based on the primordial tie or the "longing not to belong to any other group". Between these broad and narrow definitions of "ethnic groups" one is proposed by Yinger (1985), which is subscribed to here and defined as "a segment of a larger society whose members are thought, by themselves and/or others, to have a common origin and to share important segments of a common culture and who, in addition, participate in shared activities in which the common origin and culture are significant ingredients". Ethnic business literature tends to define ethnic groups in terms of their foreign national origin and as Light suggests "Ethnic economies depend upon ethnicity not national origins for their boundaries and national origin is just a convenient indicator of ethnicity, not the real thing" (Light and Gold, 2000). The presented case here contributes to the understanding of what "Ethnic" means in ethnic businesses. Not only separate (sub) ethnic business networks, such as those found by Light in his study of Iranians in Los Angeles (Light et al., 1991), but also a hierarchy of (sub) ethnic groups from the same country and a pattern of overlapping ethnic identities. Besides the study adds a new perspective; that is another further move beyond boundaries of ethnicity and closer to the core cluster of individuals or controlling elite, the inner circle, entrance in which requires ethnic solidarity only as a minimum of conditions to be met. Even stronger ties will be required, as far as the inner circle (the insiders within the larger ethnic group) through historical struggles and strategies have established privileged positions. Evidence in this case shows that only being from Turkey does not give access to employment at DHB Bank but belonging to the Turkish-Turkish ethnicity and not to a Turkish-Kurdish ethnicity has a major importance in obtaining a position. This is seen in the composition of the board of directors, branch managers and other staff across the organization.

A third theoretical topic of relevance for the study is that of business relationships within and across ethnic groups. Granovetter (1973) pointed to the importance of "weak ties" while "ethnic business" literature suggests the importance of "strong ties" seeing the locational clustering of immigrant businesses as economic advantage (Light and Gold, 2000). Taken together this literature suggests that immigrant businesses flourish in close-knit immigrant communities-"the network advantage" and in economic sectors where they enjoy a competitive advantage due to their cultural insight and knowledge-"the cultural competence advantage". Usually, therefore, immigrant businesses are strong in city areas where many immigrants live and in sectors which deal with culture-loaded goods and services.

The issue of the immigrants' concentration in specific economic sectors where they enjoy a competitive advantage due to their cultural insight and knowledge-"the cultural competence advantage" can also turn to become a disadvantage due to the fact of redundancy in business contacts "to the extent that they lead to the same people and so provide the same information benefits" (Burt, 1992). Therefore concludes Burt (1992) in referring to Granovetter (1973) "information circulates at a high velocity within these clusters. Each person tends to know what the other people know. Therefore and this is the insight of the 
argument, the spread of information on new ideas and opportunities must come through the weak ties that connect people in separate clusters, hence the strength of weak ties. Weak ties are essential to the flow of information that integrates otherwise disconnected social clusters into a broader society”. The Case of DHB Bank shows that the bank has been aware of the fact of a "possible" ethnic disadvantage and has decided to locate the main branch in a "non-Turkish" area of Roterdam and is very selective in business co-operation with Turks residing in Europe and prefers doing business with Turks residing in Turkey.

\section{MATERIALS AND METHODS}

Methodology and case introduction: In the following section the organization of DHB Bank, in which the dominance of co-ethnic employees and clientele across borders is the key organizational characteristic, will be outlined.

DHB Bank is only one of the actors in the financial network of Turkish owned banks in Germany and its neighboring countries. It was during a stay in Hamburg where I carried out a field study regarding "International Trade through Ethnic Networks" that I discovered the existence of this kind of financial network. The decision to select DHB Bank for further analysis was taken due to the bank's success in growth, its huge increase in market share and the expansion in its number of retail branches across North European cities: These facts were also confirmed by DHB Bank's different competitors, both in Hamburg and Rotterdam.

The methodology of the case has been that of conducting interviews with eight named interviewees and two who wished to remain anonymous, amongst DHB Bank employees and their business network in Rotterdam and Hamburg (the interviews consisted of one telephone and seven face-to-face interviews). The interviews were partly explorative in nature and partly structured by way of an interview guide. Questions and answers were presented orally and notes were taken during the interviews. As a supplement to the qualitative data some quantitative statistical data were used. These were based on "Financial Statements 1999" and "Financial Statement 2008" (the most recent available) forwarded to me by DHB Bank and previous "Financial Statements" and other relevant information provided by DHB Bank on their Internet homepage. To make a comparative investigation and examine the role of the other Turkish owned banks in the EU, additional interviews were conducted with three other Turkish owned banks operating in the EU (Ziraat Bankasi, T.C., Mr. Jorg Vahlenkamp, Deputy Subbranch Manager,
Hamburg, Germany, ISBANK GMBH, Mr. Murat Guclu, Hamburg, Germany, United Garanti Bank International N.V., Rotterdam, the Netherlands). Furthermore, three other interviews were conducted with the Turkish General Consulate (Mr. Zihni Turgul, Attache of Trade and Ms. Selma Tarhan, Attache of Education) in Hamburg as well as with the special legal advisor in immigration issues for the "Senate of Hamburg” (Mr. Rainer Albrecht, Die Ausländerbeauftragte, Referent für Ausländerrecht, an den Senat, Hamburg). The names of non-anonymous interviewees can be found in endnotes.

Rotterdam is the largest "Container Harbor" of the world (Information provided by Demir-Halk Bank. The interviewees were: Demir-Halk Bank, Netherlands N.V., Mr. Merdan Araz, Senior General Manager, Head Office (telephone interview), Ms. Anke Tamer, Senior Supervisor, Head Office and Mr. A. Sami Açar, Head of Hamburg branch) Demir-Halk Bank (Since January 2000, Demir-Halk Bank has presented itself to the public under the name of DHB Bank) (Netherlands) N.V. has its main office in the opposite side of the harbor, in the "Park Laan" area, the fashionable financial and trade centre of Rotterdam which provides financial and customs services to world-wide traders. DHB Bank (Netherlands) N.V., established as a commercial bank under Dutch law in 1992, is controlled by two shareholders, one privately owned Turkish bank and one state-owned bank.

\section{RESULTS}

Bank profile: Demir-Halk Bank (Netherlands) N.V., established as a commercial bank under Dutch law in 1992, is controlled by two shareholders. $70 \%$ of the bank's capital is held by Demirbank T.A.S. of Istanbul, a privately owned bank whose shares are traded on the stock exchanges of Istanbul, Frankfurt and Munich. The remaining $30 \%$ is owned by Türkiye Halk Bankasi A.S., Turkey's second-largest stateowned bank in terms of asset size (DHB Bank, Financial Statements 1999. The "Financial Statements 1999" have been prepared by DHB Bank's Executive Board and audited by KPMG Accountants N.V.) Both banks were looking to expand their business into Western Europe and opted for an independent subsidiary headquartered in the Netherlands rather than a simple expansion of their branch network. According to the interviews, Dutch financial legislation regarding establishing a commercial bank is the most liberal in the EU and once establishment has been legally recognized then a bank can operate as would any other EU bank across the EU. 
Since January 2000, Demir-Halk Bank has presented itself to the public under the name of DHB Bank. While the statutory name entered into the company register with the Rotterdam Chamber of Commerce remains unchanged, it was felt that the new, shorter, trade name would better express the bank's dynamic organizational culture and the international character of its business (DHB Bank, Financial Statements 1999).

Mr. Merdan Araz, Senior General Manager of DHB Bank, describes the role and ambitions of DHB Bank as follows:

"We want to become a leading European provider of trade finance products and services to a global clientele for their Turkish business. To reach this goal we seek to offer excellent customer service in every transaction. Continuously, we work on building long-term relationships with our clientele. Our expertise in the Turkish market is our most important competitive asset. Therefore, we strive to always have a finger on the pulse of the Turkish economy, to keep up to date on the innovative developments in this highly dynamic business environment. In other words: No matter where you are located-if your business involves Turkey talk to us"

The above quotation can actually be interpreted in a way that no priority is given to Turkish owned businesses and the key to the success of DHB Bank is to be found in their multicultural and multi-linguistic competencies that lead to a higher level of mutual understanding and mutual trust relationships which in turn lead to a strengthening of business relations. According to the interview with Ms. A. Tamer, Senior Supervisor at the head office, DHB Bank's trade finance activities also involve two Danish banks (Denmark is a country with a large Turkish migrant community where no Turkish owned bank exists). According to the interviews it seems that DHB Bank targeting financial cooperation with all countries where there is a significant number of Turkish migrants and to achieve the goal, where there is no Turkish banks in the country they start co-operation with local banks in order to attract business and serve the local (Mr. Zihni Turgul, Attache of Trade and Ms. Selma Tarhan, Attache of Education).

Trade finance is in the centre of DHB Bank's business activities. The bank facilitates the trade links between Turkish corporations and their business partners world-wide. Letters of Credit (L/C) (According to DHB Bank L/C is defined as: A documentary credit issued by a bank ("issuing bank") at the request of a customer ("applicant") in favor of a third party ("beneficiary"). It entitles the beneficiary to payment for goods sold by him to the applicant against presentation of a specified set of shipping documents and is usually forwarded to the beneficiary by a correspondent bank of the issuing bank ("advising bank"). A confirmed L/C exists when: an advising bank adds its confirmation to a documentary credit and makes its own, independent payment commitment in addition to that of the issuing bank. The confirming bank thus assumes the credit risk of the issuing bank and the political risk of the applicant's country) are at the heart of DHB Bank trade finance business. The particular strength in this field is rooted in the expansive network of relationships with banks in Turkey. DHB Bank confirms letters of credit issued by many Turkish banks as well as issuing letters of credit for clients world-wide. Upon the presentation of satisfactory documents, sight L/Cs can usually be paid within a maximum two working days. DHB Bank also discounts deferred and acceptance L/C's that have been confirmed or issued by itself as well as providing advisory services on the technical details of documentary credits.

DHB Bank issues letters of guarantee (According to the DHB Bank, a letter of guarantee is defined as: a declaration on the part of a bank stating its commitment to pay the specified amount in case of non-performance by the principal debtor) in various forms, such as payment guarantees, bid bonds, performance bonds or advance payment guarantees: These are issued on behalf of banks or corporations in favor of financial institutions as well as for corporate clients and the bank also accepts counter-guarantees from almost all banks in Turkey against issuing letters of guarantee by itself as well as risk sharing. Apart from services related to documentary credits, DHB Bank also discounts on drafts, bills of exchange and promissory notes available from Turkish banks.

DHB Bank also executes international payments in all major currencies and provides account services for commercial clients as well as advice on investment opportunities in Turkey. Some special services, such as foreign exchange deposits with the Central Bank of Turkey as time fixed deposits with the possibility of high interest rate return on the US dollar and EUROAND investing in capital market instruments, such as Treasury paper or equities, can also be mentioned as some of DHB Bank's activities.

DHB Bank also offers a range of retail services through its branches in the Netherlands (Amsterdam, 
Rotterdam, The Hague and Utrecht) as well as foreign retail branches for instance in Germany and Belgium. The Turkish population in these countries are the most frequent clientele. One of the reasons here is the ease and speed with which money transfers to Turkey can be handled through DHB Bank and this fact can also be confirmed by other competing banks such as the Hamburg branch of the state owned T.C. Ziraat Bankasi, this bank being the largest state owned Turkish bank (with its more than 1300 branches across Turkey), the Hamburg branch of the Turkish private bank IS Bank GmbH and the Rotterdam branch of another private Turkish bank, United Garanti Bank International, Nederland N.V. Through the vast branch network of DHB Bank's shareholder, the Turkish based "Halkbank", transfers can be easily made-even to the most remote areas of Turkey. Some other financial services such as; demand account, time fixed accounts and children accounts can also be mentioned as a part of the activities.

DHB Bank's operations and business focus in Germany, the Netherlands and also in Belgium are of the same unvarying nature.

The focus of DHB Bank's activities remains on the financing of trade flows between Turkey and its global partners, with an emphasis on northern Europe. At the same time, the provision of retail services through the bank's branch network is gaining importance and the range of products offered to private customers is being expanded.

In order to serve its corporate and individual clients better, DHB Bank continued to add new locations to its branch network and operations in Western Europe since 1999 and still in 2008 the same strategy is continued.

A retail branch in Kassel, Germany, was opened in January 1999. The bank's operations in Belgium began with the opening of the Brussels branch in October 1999and further expansion in Europe was introduced with a branch in Cologne, Germany, in spring 2000. The bank continues to expand and in 2001 branches in Munich, Stuttgart, Antwerp and Berlin was a reality. Beside that the bank has expanded with 19 branches and sub-branches in Macedonia. As seen in Table 2, in 2008 the bank has 33 branches.

DHB Bank's operations in Germany started with the opening of a retail branch and, later, a main branch in Düsseldorf in 1997. This was followed in 1998 by the opening of the Hamburg branch, in February 1999 the Kassel branch and in 2000 the Cologne branch (DHB Bank N.V., 1998). Germany is the most promising market for the DHB Bank, due to being Turkey's largest trade partner, both as a source of Turkish imports and as an export destination as well as also being the only EU country with approximately 3.5 million migrants descending from Turkey. Below, DHB Bank sees its position as follows:

\begin{abstract}
"Since we concentrate on the business of financing international trade, Germany holds great potential for our operations. Of course, we also offer banking services for private customers through our retail branch. There our main target market is the Turkish population. In particular, the major cities of Western Germany are home to many people of Turkish origin. They appreciate Demir-Halk Bank for the way we do business: We speak their language and offer services that are an important part of their banking needs. In particular, money transfers to Turkey can be rapidly and conveniently processed and at a competitive price, helped by our shareholder Halkbank's vast network of branches covering just about every area of the country"
\end{abstract}

DHB Bank's representative office liaises with Turkey, the bank's most important market. DHB Bank expresses the importance of the Istanbul representative office as follows:

"The representative office maintains close contacts with our corporate customers in Turkey and introduces our bank to potential clients there. During company visits our representative gathers data which are later used for credit analysis at the head office (Rotterdam). To some extent the representative office itself contributes to this kind of task through its financial analysis desk. Further, through the representative office we obtain upto date general information about the developments in the market and the dynamics of the business sector. With the fast-paced change in Turkey's business environment this is very important for our bank"

The period of 1999-2006 has been of sustained growth for the bank. Business volume and asset size continued to increase and income rose considerably compared almost year by year. An intensified marketing effort has further strengthened the bank's position in its core business, the provision of trade finance and retail services. At the same time, high real interest rates in the Turkish fixed-income and money markets continued to contribute to the bank's profitability. 
Am. J. of Economics and Business Administration 2 (3): 253-265, 2010

Table 1: Financial highlights and staffing growth

\begin{tabular}{lrrrr}
\hline NLG 1000/year & \multicolumn{1}{c}{1997} & 1998 & 1999 & $1997-99(\%)$ \\
\hline Total assets & 1333810 & 1374768 & 1836756 & 38 \\
Loans and advances & 64775 & 765849 & 906205 & 1299 \\
Funds entrusted & 216283 & 335716 & 795237 & 268 \\
Shareholders' equity & 111875 & 116204 & 121829 & 9 \\
Net interest income & 19669 & 55741 & 81655 & 315 \\
Net commission income & 6964 & 9392 & 11330 & 63 \\
Result after tax & 6728 & 783 & 9125 & 36 \\
Number & 79 & 104 & 156 & 97 \\
Number of employees (December 31) & 7 & 8 & 10 & 43 \\
Number of branches & & & \\
\hline
\end{tabular}

Source: Own calculations based on DHB Bank’s “Financial Statement 1999” (DHB Bank N.V., 1999)

Table 1 illustrates the financial highlights and staffing growth in DHB Bank for the 3 year period of 19971999. The Table 1 is based on the data provided by DHB Bank in the "Financial Statement 1999". Aside from the financial growth another important issue is the growth in the number of personnel and number of branches. Comparing staffing level data from 31 December, 1997-31 December, 1999 shows a growth from 79 employees to 156. According to an interview with Ms. Anke Tamer, Senior Supervisor of the Human Resources Department at DHB Bank's Head Office, the number of employees at the end of March 2000 had risen to 175 and the number of the employees is likely to continue increasing due to the establishment of new branches mostly in Berlin.

\section{DISCUSSION}

Further investigation into the employees' ethnic background illustrates a heavy concentration of Turkish employees. According to the interview with Ms. Tamer only 8 out of 175 employees are not of Turkish descent. According to Ms. Tamer, in some cases, Dutch legislation demands that some employees must be of Dutch descent and having Dutch citizenship. This is the case when dealing with the "executive board" of a financial institution. In this case, it is required by legislation that at least one-third of the board must be of Dutch descent. The effect of this legislation is evident when looking on the executive board of DHB Bank consisting of three general managers, two of Turkish descent and one of Dutch descent. Further investigation shows that among the Turkish staff is also a kind of hierarchy where citizenship of Turkey is not sufficient and the issue of a final relations and being of Turkish descent has significance. That comes to surface when interviewing that most Turkish staff is having a Turkish-Turkish background rather than a TurkishKurdish background. The data indicating that the bank sees the key to its success as having a very selective hiring strategy where a final relations, co-ethnic and sub-ethnic relations have priority.
Table 2: Financial highlights and staffing growth

\begin{tabular}{lrrr}
\hline Euro 1000/year & \multicolumn{1}{c}{2008} & \multicolumn{1}{c}{2007} & \multicolumn{1}{c}{2006} \\
\hline Total assets & $2,225,188$ & $1,909,012$ & $2,122,879$ \\
Loans and advances & 690,584 & 631,586 & 561,862 \\
Funds entrusted & $1,747,209$ & $1,521,615$ & $1,632,667$ \\
Shareholders' equity & 205,246 & 211,612 & 204,687 \\
Net interest income & 37,827 & 42,923 & 47,284 \\
Net commission income & 12,321 & 9,358 & 10,283 \\
$\begin{array}{l}\text { Result after tax } \\
\text { Number }\end{array}$ & 7,908 & 18,683 & 15,011 \\
Number of employees & & & \\
(December 31) & 471 & 241 & 298 \\
$\begin{array}{l}\text { Number of branches } \\
\text { (including 19 branches and }\end{array}$ & 33 & & \\
SUB-branches in Macedonia) & & & \\
\hline Source Based & & & \\
\hline
\end{tabular}

Source: Based on DHB Bank's "Financial Statement 2008” (DHB Bank N.V., 2008)

As showed in Table 2 and also in comparison with Table 1 (hence here the difference in NGL and EURO), the bank has been subjected to remarkable changes in decisive economic key factors nonetheless due to financial crises around mid 2006 and 2007. In spit of that it is worth to remark the significant intake in number of employees in 2008 which has risen to 471 persons after a decrease in 2007. The trend is still the same as in late 1990's there is an overrepresentation of Turkish born staff and there is a ruling discourse of "Bounded Ethnic Solidarity".

Ms. Tamer, who is of German descent, stated that one important reason why she is working at DHB Bank is that her husband, who is of Turkish descent, is also working there as a senior manager. She also emphasized that employees at DHB Bank do have something more than professional relationships in common. They have some sense of affinity and/or cultural ties which link them together and one of the strongest common ties is the employees' Turkish background.

Figure 1 illustrates the relationship between DHB Bank's Head Office in Rotterdam, retail branches in the Netherlands, the Istanbul representative office and the foreign branches in different European countries and the name of its top management as in 2000. The Fig. 1 also shows the organizational diagram of DHB Bank and the composition of the "Supervisory Board". 
Am. J. of Economics and Business Administration 2 (3): 253-265, 2010

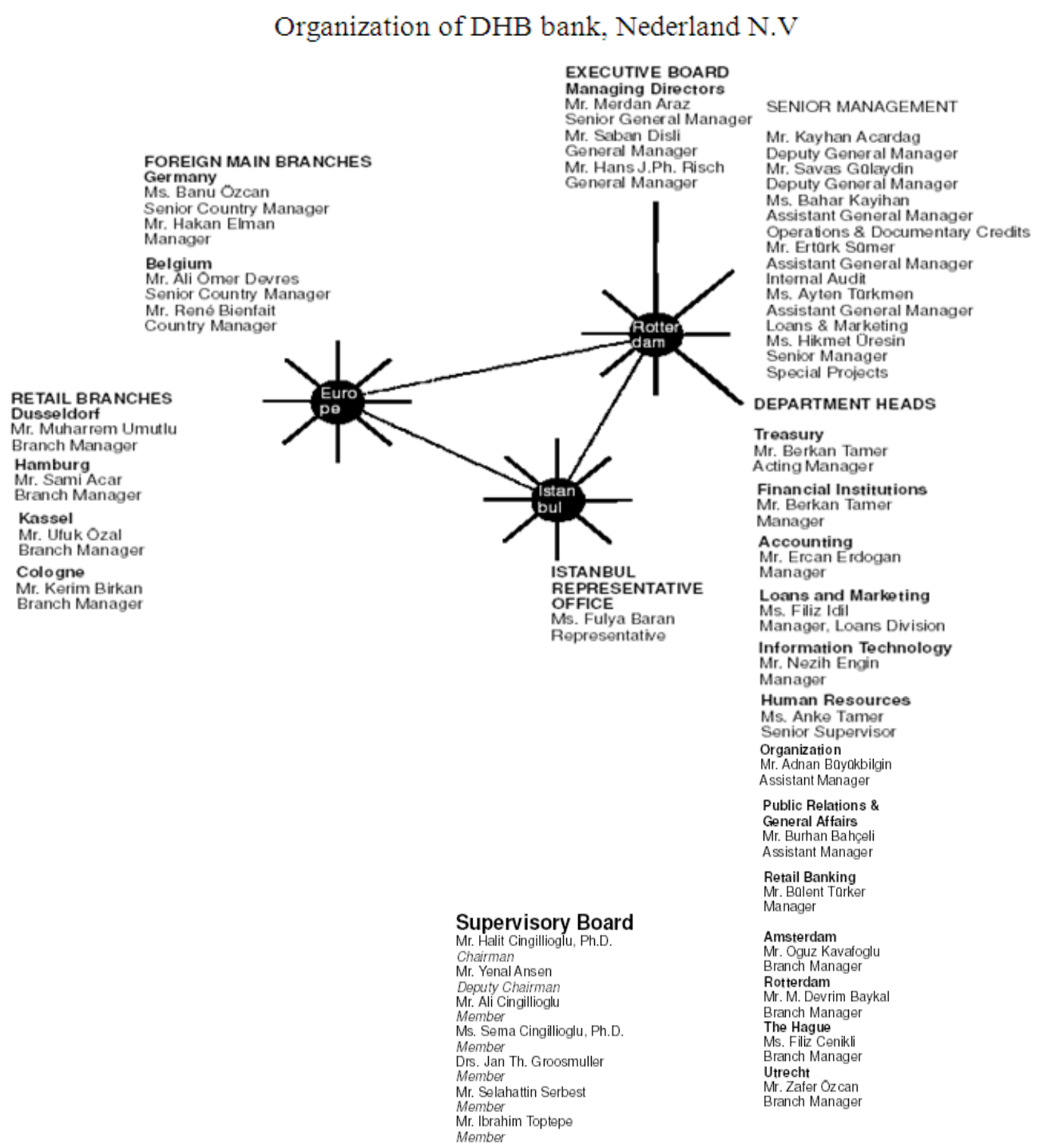

Fig. 1: Based on the interviews and DHB Bank's "Financial Statement 1999-2008"

As shown in Fig. 1, the "Executive Board" is in charge of the whole organization and is located at the head office in Rotterdam. "Senior Management" and "Department Heads" are also located at the head office under the direct control of the "Executive Board". The "Retail Banking" department controls the retail bank branches in the Netherlands. The "Executive Board" is also in charge of "Foreign Main Branches". The foreign "Retail Branches" are controlled by "Foreign Main Branches". The "Istanbul Representative Office" acts in a liaisory capacity to Turkey, being under direct control of the head office and also used by retail branches. The "Supervisory Board" is an independent advisory and controlling body.
The location of the Turkish business community in Rotterdam and patterns of ethnic segregation: Looking closely at Rotterdam inner city, the broken lines in the map below (Fig. 2) show two different sides of the city centre around the central train station. One is the fashionable city centre with a vast number of shops and daytime activities and the other one is the less attractive part of the city centre where-in a tight geographic concentration consisting of a few adjacent streets-a huge number of nightlife activities and immigrant shops can be found. A part of the city centre where a heavy concentration of Turkish businesses can be found-is encircled in the map below and marked "A". 


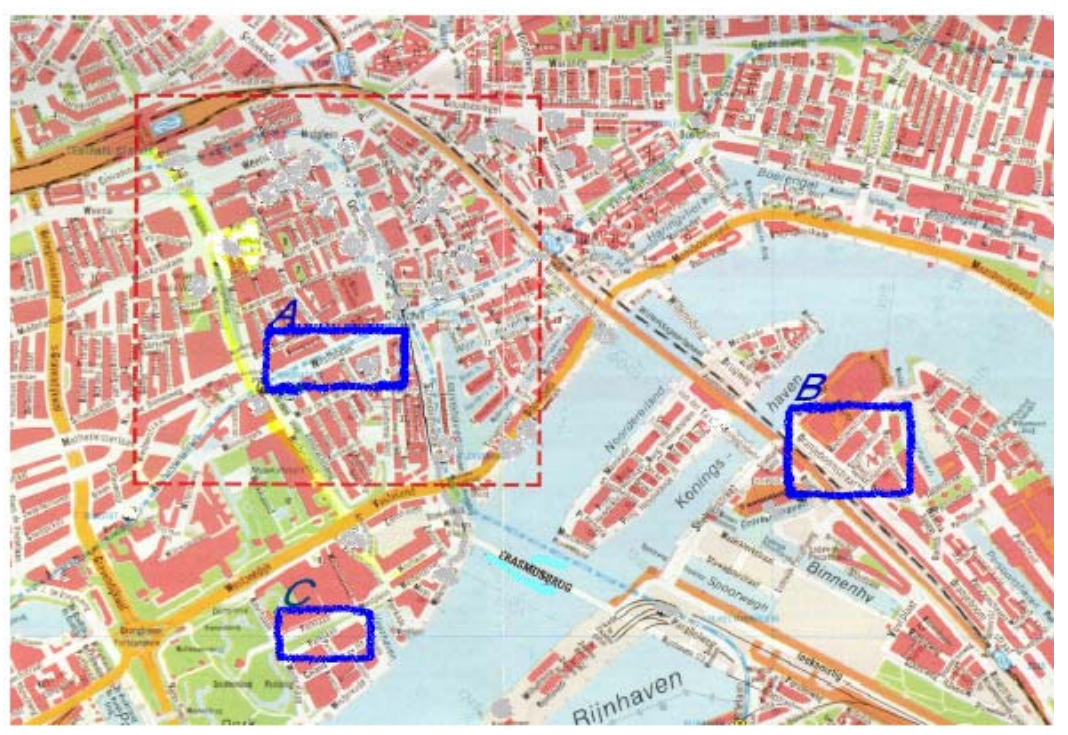

Fig. 2: City map of Rotterdam, Rotterdam city council

The area is located in a street called "Westblaak". The "Westblaak" area can be divided into two parts: One is comprised of different shops which form a cluster more or less at one side of the street. On the other side of the street, Turkish financial institutions, travel agencies and other Turkish service supplying businesses are grouped together close to the Turkish General Consulate, which is located at "Westblaak No. 8”. DHB Bank's retail branch in Rotterdam is located at "Westblaak No. 10" and it is along this street that most of the other Turkish owned banks represented in the Netherlands (The Turkish owned banks in the Netherlands are, in alphabetical order, as follows: AK Bank, DHB Bank, Emlak Bank, Finans Bank, IS Bank, Koc Bank, T.C. Ziraat Bank and United Garanti Bank International (UGBI). Most of these banks are operating as foreign branches of Turkish banks and a few of them as Turkish owned Dutch banks) are located. The Turkish owned business concentration on this side of the street ends at the corner of the block with another Turkish owned bank "United Garanti Bank International, Nederland N.V." being located at "Westblaak No. 34".

Almost all Turkish owned banks in the Netherlands are also represented by their counterpart in Germany and through cross border networking the Turkish owned financial institutions in the EU have established a linkage between the "Turkish Diaspora" and the "Motherland Turkey".

Section of Rotterdam city: The encircled area "B" in Fig. 2 shows the dwelling area of "Oranjeboomstraat".
This area is known as an area with a high concentration of migrants, mainly of Turkish descent. Even so, the area is only residential and there is almost no immigrant business activities to find here.

The encircled area "C" in Fig. 2 shows the fashionable area of "Park Laan" where a number of financial institutions, shipping and trade agencies are concentrated. The "Park Laan" area is situated on the opposite side of Rotterdam Harbor. Almost all business activities here are conducted by Dutch owned firms. DHB Bank's Head Office is also located in this area.

In every respect the year 1999 and 2006 was a very successful year for DHB Bank (DHB Bank N.V., 1999; 2006). Looking on the banks history and taking into consideration the huge global financial crises, one must admit that the banks overall results has been a success although the relatively decrease in result after tax in 2008 compared with 2006 Table 2. In spite of that the number employees has risen in 2008, nonetheless due to "bounded monotonic solidarity". However, when asked the question: "Does the DHB Bank treat Turkish small shopkeepers or other immigrant small business owners more positively in respect of greater number of loan approvals compared to western European banks?”, Ms. Tamer answered as follows:

"In DHB Bank we are bankers, we look at the business plan. If it is solid, we take the risk and approve the loan. In general, one could say that if the small business owners, regardless ethnic background, have not been able to obtain loans from our competitors they 
wouldn't be able to obtain loans from us either, as well as the fact that their business credit needs are too small and the bank either earns very little or nothing at all on these small business credits. A bank cannot afford to get involved in uncertain businesses. Banks are not charities and we do have our obligations to stockholders and depositors. On the other hand, we do have small business owners who are holder of accounts in the bank and their income is not less than regular wage-earners. We do not discriminate against other Turks or other minorities, but rejection is a question of creditworthy"

In spite of this non-ethnic policy of the bank which seems a fair interpretation of the above quotation, it is rather paradoxical to observe that most of the clientele are Turkish business owners and DHB Bank's retail branches are located more or less together with all the other Turkish owned banks in different North European cities, although according to Fig. 2 the head office is not located in immigrant concentration area.

A stable and growing Turkish economy since late 1990's until mid 2006 has offered new opportunities in DHB Bank's core business since trade flows between Turkey and Western Europe are bound to grow even further. This is also to be traced in comparison between Table 1 and 2 when looking at the increase in number of branches. While Ms. Tamer expresses optimism about the development of DHB Bank's business opportunities, she also states that DHB Bank expects competition for Turkish business to intensify and that will potentially put pressure on profit margins. She explains, therefore, that DHB Bank will further step up its marketing effort directed at corporate clients as well as banks so as to strengthen the niche position being built up.
At the same time, increased attention will continue to be devoted to the bank's retail business. While efforts so far have been focused on widening the deposit base by offering new liability-related products and due to this fact has DHB bank since year 2000 expanded the range of services also offered on the asset side.

Studies by DHB Bank has been carried out to establish the feasibility and profitability of such possible products, including consumer loans, bank cards and mutual funds as well as brokerage services in mortgages and/or insurance and as result since early 2000 until mid 2006 the bank gradually started to offer these services.

DHB Bank expects that an expanded product range would enable the bank to utilize the full potential of the established network of retail branches and the intensive client contacts that have been built up over recent years. During the last few years, the physical expansion of the branch network had been a reality. As presented in “Table 3-Timeline for DHB Bank” a number of new retail branches such as in Cologne, Germany, has been opened and further locations in Germany are in the planning phase or carried out. These efforts have also led to many new branches across Europe.

The management of DHB Bank is constantly studying the possibilities offered by the Internet in terms of the bank's commercial objectives. As the first basic consumer applications went online in 2000 it has been expected that the technical infrastructure for Internet banking will be developed further in years to come and become more advanced. On the funding side, DHB Bank aims to further broaden its deposit base through increased retail activity while at the same time attracting new wholesale funding in the syndicated loans market. In line with the anticipated further growth of the bank's business activities and the ongoing geographical expansion, DHB Bank also expects further increases in the number of staff in the years to come.

Table 3: Timeline for DHB Bank

1992 DHB Bank (Nederland) N.V. was incorporated

1993 Commenced operations in April 1993

1995 Amsterdam and The Hague branches opened

1996 First syndication was secured \$45M. Istanbul rep. office was opened

19973 syndications secured DEM 50M, \$30M, \$40M. Rated by Thomson BankWatch

1998 Internet site launched. Düsseldorf and Hamburg branches opened

1999 Brussels branch opened. Consumer banking activities started and established call center.

2000 Opened Cologne branch. Mortgage and Insurance subsidiary established. Capital increased to 113M. 70\% shares transferred to BRSA

2001 Munich, Stuttgart, Antwerp and Berlin branches opened. DHB Netbanking and consumer lending is launched.

2002 Disbank N.V. was acquired. 70\% shares of DHB Bank (Nederland) N.V. bought equally by Mr. Halit Cingillioglu (and transferred to HCBG Holding B.V. in 2003, solely owned by Mr. Cingillioglu) and Mr. Aydin Dogan

2003 Implementation of self developed banking software Matrix. Debit cards and ATM

2004 Activity in new markets (CIS). Initiation of structure trade finance activities. Introduction of credit card insurance

2005 Upgraded by Fitch to BB. Website being awarded 5th place in Dutch banking sector. Chosen to be the best bank in deposits by EURO Finanzen in Germany. HCBG Holding controls 70\%

2006 Launching of Turkije Hypotheek (mortgages to European residents for real estate purchase in Turkey). Chosen the best bank in deposits by EUROfinanzen for the second time. Largest (\$ $200 \mathrm{mio}$ ) and best priced syndication of DHB Bank (Nederland) N.V.

2007 Fitch rating dropped. New rating from Moodys: BA1 (equivalent of BB+, representing an upgrade)

2008 Acquisition of 66.56\% stake in Export and Credit Bank Inc., Skopje. Ba2 rating from Moody’s. 


\section{CONCLUSION}

From the outset, trade finance has been a major business focus for DHB Bank. This made it appear logical to locate at the Dutch city of Rotterdam. The specialty of DHB Bank is the provision of trade finance services for Turkish corporations and small businesses and their Western European business partners. Since Turkey is the most important market for DHB Bank, the Istanbul representative office liaises between DHB Bank and Turkey.

Soon after its establishment, DHB Bank began to expand the retail services it provided, mainly to Turkish Diaspora in the Netherlands. In 1997, DHB Bank took its first step towards building an international presence in the European market and established the Düsseldorf branch. This development has continued in a way that today the activities of DHB Bank can be found in several German cities as well as Belgium and there are also plans for establishing activities in many other European cities. Thus, DHB Bank is now a Turkish owned bank, registered in the Netherlands as a Dutch bank under Dutch legislation and operating across northern Europe.

Since its modest beginnings in 1992, Demir-Halk Bank has come a long way. The bank has a paid-up capital, with a multi billion Euro balance sheet over the years. In step with the continuous expansion in DHB Bank's business volume, staff numbers have also grown. The dominant organizational characteristic is the strong dominance of monoethnic and coethnic employees and clientele of Turkish descent. Although the bank's policy and services have not been developed with the ethnic community in mind, in practice the operation of the bank is quite mono-ethnic when it comes to client type and employees.

A stable and growing Turkish economy has offered new opportunities in DHB Bank's core business since trade flows between Turkey and Western Europe are bound to grow even further. At the same time, the improved economic situation and financial capacity of Turkish migrants and Turkish business owners residing in the northern European countries will ensure that the growth of DHB Bank will continue. Therefore, increased attention will continue to be devoted to the bank's retail business.

The general impression gained from the interviews is that there is no doubt that DHB Bank wishes to maintain its leading position amongst its fellow Turkish competitors and to achieve this is expanding its retail branches in north European cities in areas with high concentrations of Turkish Diaspora owned businesses. In so doing, DHB Bank will be able to attract the increasing number of successful Turkish business owners whose business location can be found in these high density areas as well as the Turkish customers who mainly do their everyday shopping in these crowded areas. In years to come the dilemma and the challenge that DHB Bank will face is to strike the right balance between it's international trade with Turkey and trade finance which has been the major business focus for DHB Bank and the recently established and growing attractive market of increasing numbers of local successful Turkish Diaspora and Turkish business owners with improved economic situations and financial capacities residing in the northern European countries. This will without any doubt bring DHB Bank's nonethnic policy into question and will probably influence its "ethnic" character.

The historical evidence presented here illustrates the formation of one of the strongest non-Western European migrant financial centers in a Western European city, namely Rotterdam controlled by a few families where mono-ethnic bounded solidarity is to be traced in all managerial and CEO positions. Furthermore, the evidence also illustrates that the managerial staff and member of boards, both in Rotterdam, other European cities and in Istanbul, do not consist of migrant with Turkish nationality and background but different ethnic backgrounds such as Kurds but of only Turkish ethnicity. Evidence also showed the existence of a hierarchy of sub-ethnic groups from the same country (Turkey) and a pattern of overlapping ethnic identities, which challenge the mainstream "ethnic business" theory.

Furthermore, the evidence shows all the financially powerful actors such as Ziraat Bankasi, IS Bank and other competing Turkish owned banks in Western Europe, one by one, admitting losing market share to DHB Bank due to the lack of sufficient networks both in Western Europe and in Turkey. Historical evidence also illustrates the strongest kind of relationship is affinity relationships between families, where most people in DHB Bank having a final relations.

The theoretical perspectives introduced in the article as the point of reference and the arena for future theoretical articulation and conceptualization are in the following confronted with the empirical findings of the study. Dealing with ethnic economy/immigrant business involves at least three aspects: Forms of globalization; Concept of ethnic business and the shaping of business relations.

In accordance with the insight of economic sociology of immigrant businesses this study shows: That the DBH Bank started as a dream to expand Turkish financial institutions to Western Europe and in 
the beginning a relatively small close knitted unit of financial institution compared to Western European competitors through out the decades evolved into a huge financial power. That is not, however, the case for the majority of immigrant businesses, many remain small and many others close down, even those with huge financial power behind then, one example is a Saudi Arab Bank dealing with Islamic Banking established in Copenhagen but faced to close down after a few years constant economic failure. The crucial questions are firstly why and how it happed and secondly what implication the empirical case might have for our understanding of immigrant business/ethnic economy or ethnic enclave economy:

- One of the very specific features of the DHB Bank, as it has been shown here, is it's international orientation at the very early stage of development, connecting the long tradition of banking in the country of origin to the Turkish Diaspora

- The study also shows that the controlling ownership and the elite owner family has managed to keep it's privileged position by not allowing entrance to others than insiders and institutionalizing the terms of entrance and limiting it to "ethnicity" and "a final relations"

- The case challenges the importance of international networks being in place prior to internationalization of the specific industry, or it should be created/activated for succeeding in border crossing businesses

- However, the case of DHB Bank reveals much support for the idea of trading diasporas sharing features, such as strong ethnic identity and mutual dependence, informal networks based on mutual trust and family reputation and a belief in the utility of knowledge from all possible sources (Kotkin, 1994). The case, on the other hand, brings about evidence that the scope of ethnic group relevant for business success probably should be limited to those of very close relatives, not including the whole ethnic group. In other words it might not be belonging to the ethnic group in general; however it is defined, but qualifying as individuals by merits and records of trustworthiness for the membership of the relevant inner circle that counts. This might be the very dynamics of the bottom up process. On the other hand the inner circle might include individuals who are not by birth included in the constructed ethnic community, but who through a long process qualify for being subject to the trust of the inner circle-as in a final relations prevailed in the case

Turning back to the second set of theoretical prospective of relevance to this study, which of the very concept of ethnicity or of "ethnic groups" the presented case here contributes to the understanding of what "Ethnic" means in ethnic businesses. Not only separate (sub) ethnic business networks, such as those found by Light in his study of Iranians in Los Angeles (Light et al., 1991), but also a hierarchy of (sub) ethnic groups from the same country and a pattern of overlapping ethnic identities. The case reveals the theoretical and empirical need for another further/deeper move beyond boundaries of ethnicity and into the core cluster of individuals or controlling elite, the inner circle, entrance in which requires the broader ethnic solidarity only as a minimum of requirements. Even stronger ties will be required.

A third and final theoretical topic of relevance for the study described earlier was that of strong ties, weak ties, "the network advantage" and "the cultural competence advantage”. Usually, therefore, immigrant businesses are strong in city areas where many immigrants live and in sectors, which deal with cultureloaded goods and services. The case of DHB Bank shows on one hand that in the beginning this was not the case for the DHB bank but as soon as sign of crisis came and/or when DBH bank wanted to expand its market share they were "forced" to give up their "ethnic-blind strategy", therefore the evidences goes both ways. The question; however, is whether concentration in specific economic sectors by it self can safeguard the privileged position without assistance from other not directly inner circles and network, which belong to the same ethnic community. There is now empirical indication for cross-network activities and the possible role they can play.

Enednotes: The names of non-anonymous interviewees:

- Demir-Halk Bank, Netherlands N.V.: Mr. Merdan Araz, Senior General Manager, Head Office (telephone interview), Ms. Anke Tamer, Senior Supervisor, Head Office and Mr. A. Sami Açar, Head of Hamburg branch

- T.C. Ziraat Bankasi, Mr. Jörg Vahlenkamp, Deputy Subbranch Manager, Hamburg, Germany

- ISBANK GMBH, Mr. Murat Güçlü, Hamburg, Germany

- United Garanti Bank International N.V., Rotterdam, the Netherlands

- Mr. Zihni Turgul Attache of Trade and Ms. Selma Tarhan, Attache of Education. Turkish Consulate, Hamburg, Germany

- Mr. Rainer Albrecht, Die Ausländerbeauftragte, Referent für Ausländerrecht, an den Senat, Hamburg, Germany 
Am. J. of Economics and Business Administration 2 (3): 253-265, 2010

\section{ACKNOWLEDMENT}

In connection with this revised version of my article, I owe a deep debt of gratitude to DHB-Bank to assist me with relevant documents as well as the LOK programme (a research programme initiated by the Danish Government to develop new knowledge to support in their work with management and organizational changes) for their generous financial support during my time in Hamburg and Rotterdam and especially to Professor Torben Bager, University of Southern Denmark, for his professional guidance in connection with the first version of this article. Thanks also goes to all interviewees without whom this publication would not have been possible. Thanks also go to Professor Thomas Straubhaar, Dr. Hubertus Hille, both at the University of Federal Armed Forces, Institute for Economic Policy Research (Universidad der Bundeswehr)-Hamburg, for letting me use their facilities during my time in Hamburg.

\section{REFERENCES}

Aldrich, H. and C. Zimmer, 1987. Resource mobilization through ethnic networks: Kinship and Friendship Ties of Shopkeepers in England. Sociologic. Perspect., 30: 422-445. http://www.jstor.org/pss/1389212

Aldrich, H., C. Zimmmer and D. McEvoy, 1989. Continuities in the study of ecological succession: Asian businesses in three English cities. Soc. Forces, 67: 920-944. http://www.jstor.org/pss/2579708

Bager, T., 1998: Migrants as carriers of institutional and organizational forms. Papers, Migration No. 28, Danish Centre for Migration and Ethnic Studies, South Jutland University Press, Esbjerg.

Burt, R.S., 1992. The Social Structure of Competition. In: Networks and organizations: Structure, form and Action, Nohria, N. and R.G. Eccles (Eds.). Harvard, Boston, ISBN: 0071033742.

Chan, K.B., 1992. Ethnic resources, opportunity structure and coping strategies: Chinese business in Canada. Rev. Europeans des Migrations Int., 8: 117-137.

DHB Bank N.V., 1997. Annual report 1997. Rotterdam, The Netherlands.

DHB Bank N.V., 1998. Annual report 1998. Rotterdam, The Netherlands.

DHB Bank N.V., 1999. Annual report 1999. Rotterdam, The Netherlands.

DHB Bank N.V., 2006. Annual report 2006. Rotterdam, The Netherlands.

DHB Bank N.V., 2008. Annual report 2008. Rotterdam, The Netherlands.
Dimaggio, P. and W.W. Powell, 1991. The New Institutionalism in Organizational Analysis. Chicago University Press, Chicago, ISBN: 0226677087, pp: 478.

Geertz, C., 1963. Old Societies and New States. The Free Press, New York.

Granovetter, M., 1973. The Strength of Weak Ties. Am. J. Soc., 78: 1360-1380. http://www.jstor.org/pss/2776392

Granovetter, M. and R. Swedberg, 1991. The Sociology of Economic Life. 2nd Edn., Westview, Boulder, ISBN-10: 0813310334, pp: 536.

Iyer, R.G. and J.M. Sharipo, 1999. Ethnic entrepreneurial and marketing systems: Implications for the global economy. J. Int. Market., 7: 83-110. http://www.jstor.org/stable/25048787

Kotkin, J., 1994. Tribes: How Race, Religion and Identity Determine Success in the Global Economy. Random House, New York, ISBN: 0679752994, pp: 343.

Li, P.L., 1993. Chinese investment and business in Canada: Ethnic entrepreneurship reconsidered. Pacific Affairs, 66: 219-243. http://www.jstor.org/stable/2759368

Light, I., 1972. Ethnic Enterprise in America. University of California Press, Berkeley, ISBN: 0520017382, pp: 461.

Light, I., Bozorgmehr, M. and C. Der-Martirosian, 1991. The four Iranian ethnic economics in los angels. Proceeding of the Paper Presented at the Annual Meeting of The American Sociological Association, Aug. 1991, Cincinnati, pp: 23-27.

Light, I. and C. Rosenstein, 1995. Race, ethnicity and entrepreneurship in urban America. De Gruyter, New York, ISBN: 0202305066, pp: 255.

Light, I. and S.J. Gold, 2000. Ethnic Economies. Academic Press, California, ISBN: 0122871553, pp: 302.

Ong, P., E. Bonacich and L. Cheng, 1994. The new Asian Immigration in Los Angeles and Global Restructuring. Temple University Press, Philadelphia, ISBN: 1566392187, pp: 330.

Perrow, W., 1993. Small-Firm Networks. In: Networks and Organizations: Structure, form and Action, Nohria, N. and R.G. Eccles (Eds.). Harvard, Boston, ISBN: 0071033742.

Waldinger, R., H. Aldrich and R. Ward, 1990. Ethnic Entrepreneurs: Immigrant Business in Industrialized Societies. Sage, London.

Weber, M., 1968. Economy and Society. University of California Press, Bekerly and Los Angeles, CA.

Yeung, H.W.C. and K. Olds, 1999. The Globalization of Chinese Business Firms. MacMillan, London.

Yinger, J.M., 1985. Ethnicity. Ann. Rev. Sociol., 11: $151-180$. 